\begin{tabular}{|c|c|}
\hline AUG $219996 \%$ ENGINEERING DATA TRANSMITTAL & 1. EDT NO 1 Page 1 of $\frac{1}{10763}$ \\
\hline
\end{tabular}

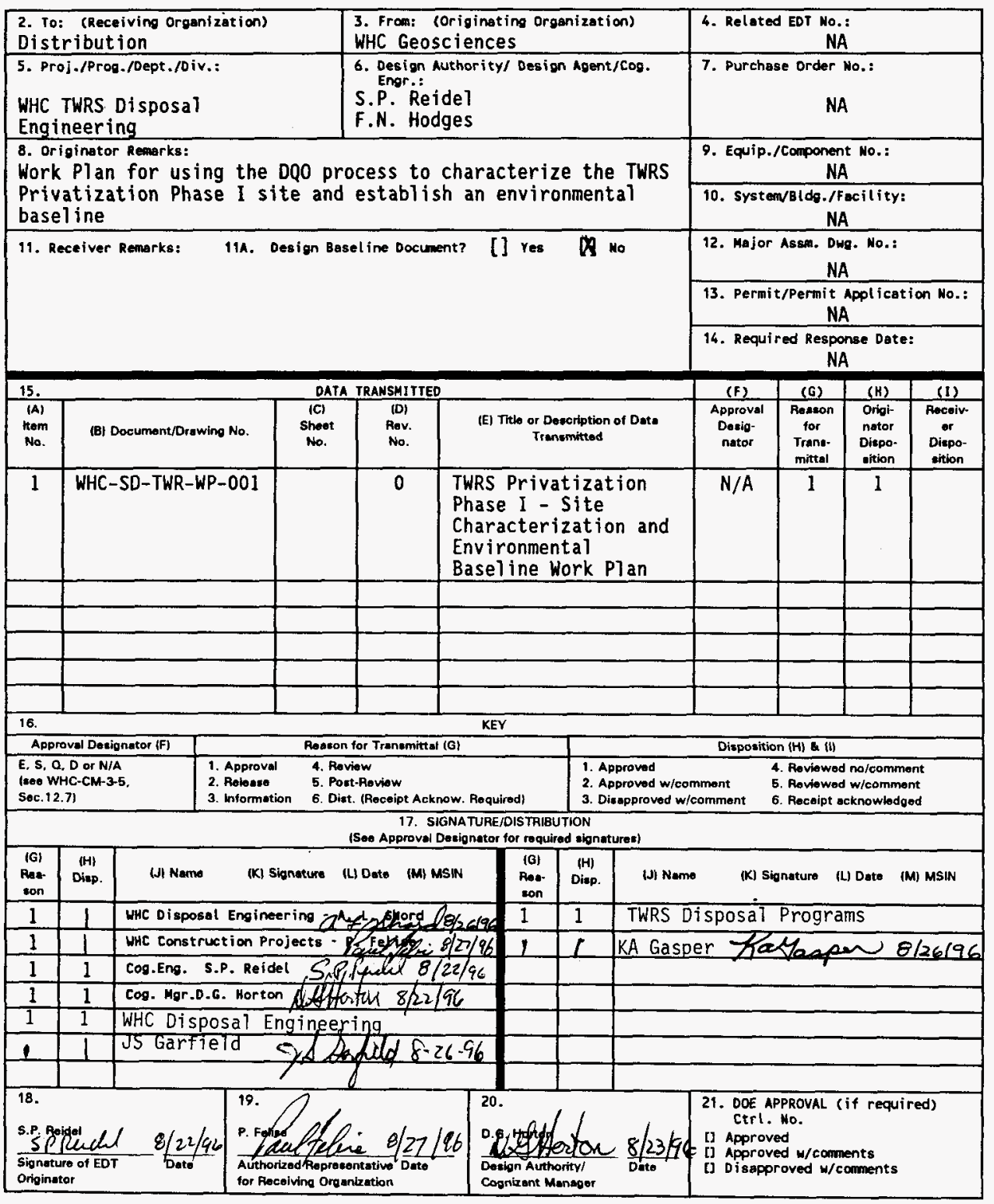




\section{TWRS Privatization Phase I - Site Characterization and Environmental Baseline Work Plan}

S.P Reidel

F.N. Hodges

WHC, Richland, WA 99352

U.S. Department of Energy Contract DE-AC06-87RL10930
EDT/ECN: 610763
Org Code: $8 \mathrm{H} 200$
UC: 721
Charge Code: D627C
B\&R Code: EW3130010
Total Pages: 6

Key Words: TWRS Privatization Phase 1, Data Quality Objectives Process, Site Characterization, Environmental Baseline

Abstract: This work plan defines the steps necessary to develop a Site Characterization Plan and Environmental Baseline for the TWRS

Privatization Phase I area. The Data Quality Objectives Process will be the primary tool used to develop these plans.

TRADEMARK DISCLAIMER. Reference herein to ony specific commercial product, process, or service by trade name, trademark, manufacturer, or otherwise, does not necessarily constitute or inply its endorsement, recomendation, or favoring by the United states Government or any agency thereof or its contractors or subcontractors.

Printed in the United States of Mmerica. To obtain copies of this document, contact: WHC/BCS Document Control Services, P.0. Box 1970, Mailstop N6-08, Richland wA 99352, Phone (509) 372-2420; Fax (509) 376-4989.
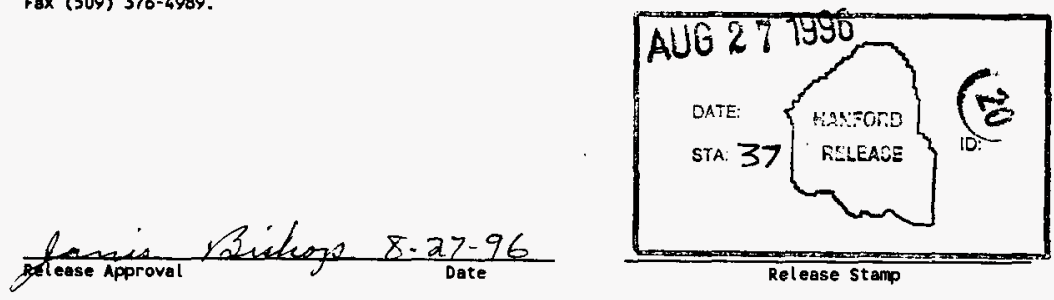
WHC-SD-TWR-WP-001, REV 0

\section{CONTENTS}

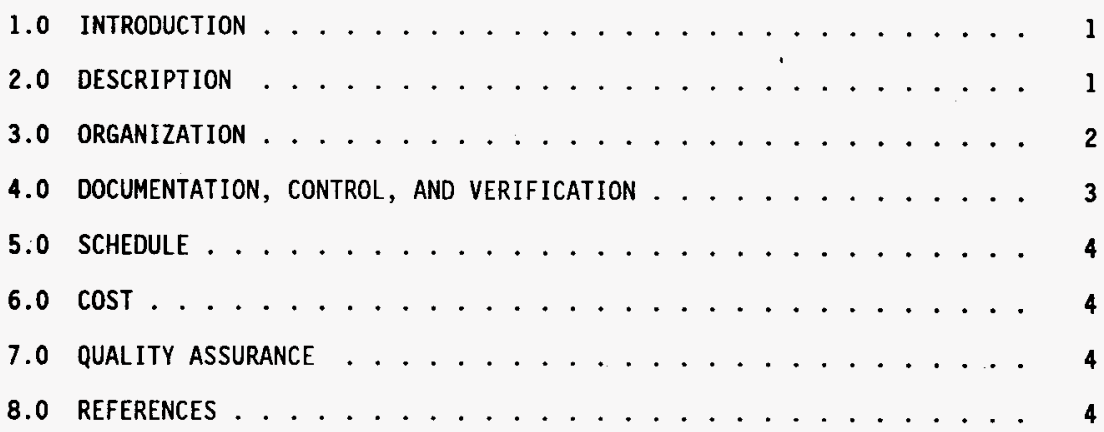




$$
\text { WHC-SD-TWR-WP-001, REV } 0
$$

TWRS PRIVITIZATION PHASE I -

\section{SITE CHARACTERIZATION AND ENVIRONMENTAL BASELINE WORK PLAN}

\subsection{INTRODUCTION}

This work plan summarizes the tasks necessary to adequately characterize and establish an environmental baseline for the selected location of the Tank Waste Remediation System (TWRS) Privatization Phase I demonstration site (Shord 1996). This establishment of baseline site and environmental conditions, required by the TWRS Privatization Request for Proposal (DOE 1996), is necessary before releasing the site to private contractors who will design, construct, and operate Phase I ("proof of concept") tank waste disposal demonstration facilities.

\subsection{DESCRIPTION}

The Site Characterization and Environmental Baseline Plan is an assessment and determination of the Phase I site and environmental data needs using the Data Quality Objectives (DQ0) approach (EPA 1993). The DQO process, mandated by the U.S. Department of Energy, Headquarters (DOE-HQ) for all environmental data collection activities, will ensure that only necessary and relevant data are acquired. This plan also will determine what data are required for preoperational monitoring to establish an environmental baseline before operation begins. The Site Characterization and Environmental Baseline Plan will be completed in two stages: Site Characterization and Environmental Baseline DQO Task, and Preparation of Site Characterization and Environmental Baseline Plan.

\subsection{SITE CHARACTERIZATION AND ENVIRONMENTAL BASELINE DQO TASK}

This task includes an assessment and determination of the Phase I data needs using the DQO process. The DQO approach will be applied to define data needs and associated field work plans. The DQO process is a systematic, costeffective approach to ensure that the type, quantity, and quality of environmental data used in decision making are appropriate for the intended use. This process involves the following general steps:

1. State the problem

2. Identify the decision to be made

3. Identify the inputs to the decision

4. Define the study boundaries

5. Develop a decision rule

6. Specify limits on decision errors, if applicable

7. Optimize design for data acquisition.

Key elements of the $D Q 0$ process as it will be applied for this characterization wi1l be developed.

The DQO process will be used to determine the data necessary to adequately characterize the site for its intended use and establish an 
environmental baseline using preoperational monitoring. The types of data that will be inputs to the decision include, but are not limited to, the following:

- Site Survey

- Soil sampling for chemicals and radionuclides of surface and vadose zone

- Surface radiological survey

- Review of existing information from the Grout Project

- Ground penetrating radar survey (near-surface [10 m] features)

- Groundwater information.

- Shallow $(<10 \mathrm{~m})$ borings.

The output of the DQO process will be a Sampling and Analysis Plan for site characterization and preoperational monitoring.

If deemed necessary, the scope of this DQO process can be expanded to include any enlargements to the Phase I area and easements for utilities or other services.

\subsection{PREPARATION OF SITE CHARACTERIZATION AND ENVIRONMENTAL BASELINE PLAN}

Once the $D Q 0$ process is complete, the Site Characterization and Environmental Baseline Plan will be written. The plan will describe the types of data that exist and the data needed. The additional data required will be described, along with the quantity and quality of the required data and a Sampling and Analysis Plan for collecting the data. The Sampling and Analysis Plan will describe the methods and sampling design.

\subsection{ORGANIZATION}

Cognizant Organization: Westinghouse Hanford Company (WHC) Geosciences D. G. (Duane) Horton, Manager/S. P. Reidel, Senior-Principal Scientist

Support Organization: WHC Near-Field Monitoring

J. J. Dorian, Technical Lead/ A. R. Johnson, Principal Scientist

The success of the DQO process depends on using experts from the cognizant and support organizations who are familiar with the Hanford Site and the data that has been collected there. A panel of experts with diverse backgrounds in site characterization will be assembled to evaluate the data needs and the ability of the available data to meet those needs, and determine what additional data is required to meet the DQOS. The scientists needed for this study, at a minimum, will include a geologist, a hydrologist, a geochemist, a biologist, and a statistician. 


\subsection{DOCUMENTATION, CONTROL, AND VERIFICATION}

The Site Characterization and Environmental Baseline Plan will be prepared and issued as a Project Hanford Management Contract (PHMC) publicly released supporting document.

Status review meetings will be held biweekly and minutes issued to involved personnel by WHC Geosciences.

In addition to the internal reviews/approvals by the cognizant and support organizations, the personnel listed in Table 1 shall conduct a review on the final draft of the Site Characterization and Environmental Baseline Plan.

Table 1. Internal Reviewers of Site Characterization and Environmental Baseline Plan.

\begin{tabular}{|c|c|}
\hline Organization & Individual \\
\hline WHC Construction Projects & P. Felise (A) \\
\hline WHC TWRS Process Design & $\begin{array}{l}\text { J. S. Garfield (A) } \\
\text { A. L. Shord }\end{array}$ \\
\hline WHC TWRS Disposal Programs & K. A. Gasper (A) \\
\hline $\begin{array}{l}\text { WHC TWRS Environmental } \\
\text { Compliance/Support Services }\end{array}$ & $\begin{array}{l}\text { D. Alison (A) } \\
\text { P. C. Miller }\end{array}$ \\
\hline WHC TWRS East Tank Farms Quality Support & $\begin{array}{l}\text { M. N. Isiam (A) } \\
\text { J. A. Upshaw }\end{array}$ \\
\hline WHC TWRS East Tank Farms Safety & $\begin{array}{l}\text { M. N. Islam (A) } \\
\text { L. E. Thomas }\end{array}$ \\
\hline $\begin{array}{l}\text { RL Environmental Assurance, Permits, and } \\
\text { Policy Division, NRP Team }\end{array}$ & $\begin{array}{l}\text { J. B. Hall (A) } \\
\text { D. C. Ward }\end{array}$ \\
\hline RL TWRS Waste Disposal & T. R. Hoertkorn $(A)$ \\
\hline RL Site Infrastructure Division & $\begin{array}{l}\text { M. J. Elsen } \\
\text { W. A. Rutherford }(A)\end{array}$ \\
\hline $\begin{array}{l}\text { PNNL Contractor Support Team/Integrated } \\
\text { Support Team }\end{array}$ & B. A. Reynolds \\
\hline ICF KH Infrastructure/Land Use Planning & $\begin{array}{l}\text { E. T. Trost } \\
\text { E. F. Yancey (A) }\end{array}$ \\
\hline
\end{tabular}

(A) indicates required approval of the plan.

ICF KH ICF Kaiser Hanford Company

NRP National Research Program

PNNL Pacific Northwest Nationa1 Laboratory

TWRS Tank Waste Remediation System

RL U.S. Department of Energy, Richland Operations Office 
WHC-SD-TWR-WP-001, REV 0

\subsection{SCHEDULE}

Based on the existing TWRS Privatization infrastructure support schedule, applicable dates are as follows:

- Start Site Characterization and Environmental Baseline Plan August 19, 1996

- Complete Site Characterization and Environmental Baseline Plan February 27, 1997.

\section{$6.0 \operatorname{cosT}$}

Total costs are estimated at $\$ 100 \mathrm{~K}$ for the Site Characterization and Environmental Baseline $\mathrm{Plan}$. This includes six person months to perform the $\mathrm{DQO}$ process and prepare the plan. Approximately one month of technical editing support is also required.

\subsection{QUALITY ASSURANCE}

The Quality Assurance plan applicable to WHC environmental activities is described in WHC-CM-7-7 and WHC-CM-7-8. Deliverables will be reviewed and approved by Quality Assurance in accordance with accepted WHC QA practices. The Site Characterization and Environmental Baseline Plan will have a Quality Assurance Project Plan (QAPP) for the Sampling and Analysis Plan.

\subsection{REFERENCES}

DOE, 1996, TWRS Privatization Request for Proposal, Sol.

No. DE-RP06-96RL13308, U.S. Department of Energy, Richland Operations office, Richland, Washington.

EPA, 1993, Data Quality Objectives Process for Superfund, Interim Final Guidance, EPA540-R-93-071, U.S. Environmental Protection Agency, Washington, D.C.

Shord, A. L., 1996, Tank Waste Remediation System Privatization Phase I Site Evaluation Report, WHC-SD- WM-SE-023, Rev.0-A, Westinghouse Hanford Company, Richland, Washington.

WHC-CM-7-7, Environmental Investigations and Site Characterization Manual, Vol 1, Westinghouse Hanford Company, Richland, Washington.

WHC-CM-7-8, Environmental Activities, Level II, Westinghouse Hanford Company, Richland, Washington. 


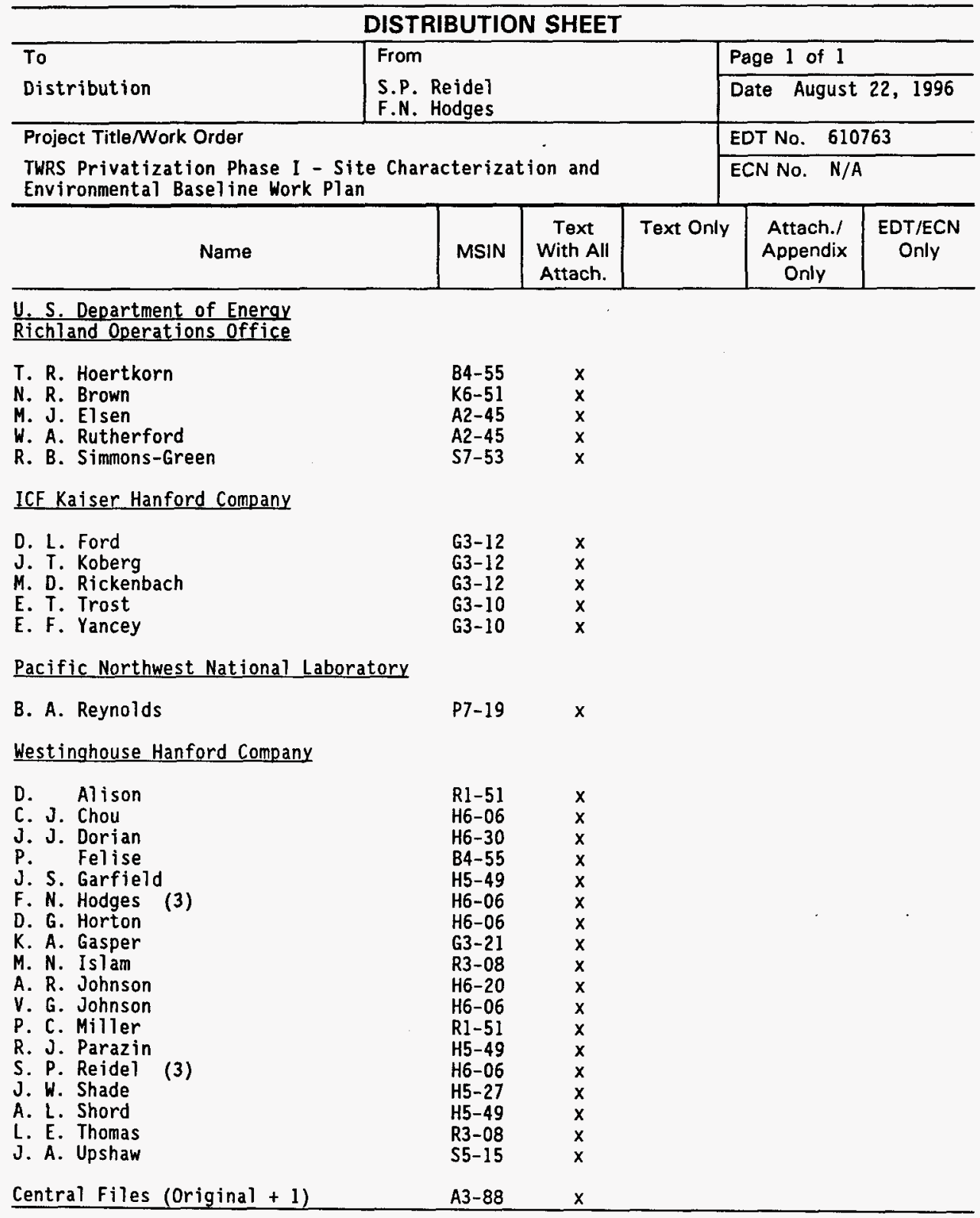

